
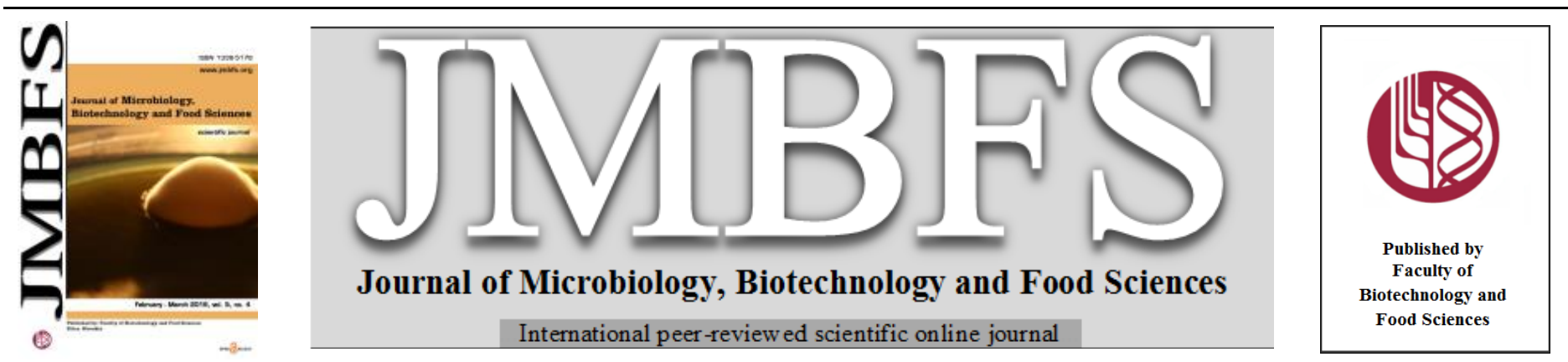

\title{
VIABILITY OF LACTOBACILLUS REUTERI NCIMB 30242 DURING STORAGE IN FRUIT JUICE AND SOY BEVERAGE
}

\author{
Denis Roy ${ }^{1,2}$, Patricia Savard ${ }^{2}$, Nancy Guertin ${ }^{2}$, Christopher J. Martoni ${ }^{3}$, Michael L. Jones ${ }^{3}$, Claude P. Champagne ${ }^{2,4}$ \\ Address(es): \\ ${ }^{1}$ Food Science Department, Laval University, Quebec City, QC, Canada. \\ ${ }^{2}$ Institute of Nutrition and Functional Foods (INAF), Laval University, Quebec City, QC, Canada. \\ ${ }^{3}$ Micropharma Ltd, Montréal, QC, Canada. \\ ${ }^{4}$ Food Research and Development Centre, Agriculture and Agri-Food Canada, St-Hyacinthe, QC, Canada.
}

*Corresponding author: claude.champagne@agr.gc.ca

doi: 10.15414/jmbfs.2016.5.4.320-325

ARTICLE INFO

Received 27. 6. 2014

Revised 22. 10. 2015

Accepted 22. 10. 2015

Published 1. 2. 2016

Regular article

open 2 access

\begin{abstract}
This study aimed to follow the viability of a probiotic culture in a soy beverage and in a fruit juice blend using quantitative PCR with propidium monoazide (PMA-qPCR). Free and microencapsulated (alginate and poly-L-lysine system) cells of Lactobacillus reuteri NCIMB 30242 were added at $10^{8} \mathrm{CFU} / \mathrm{mL}$ in each food matrix and stored for 8 weeks at 4 or $8^{\circ} \mathrm{C}$. In both matrices, viability losses during the 8 week storage period were less than $1 \log \mathrm{CFU} / \mathrm{mL}$. The $\mathrm{pH}$ of the fruit juices did not change during storage, but acidification occurred in the soy beverage, particularly when storage was carried out at $8^{\circ} \mathrm{C}$. As a result, at a pH below 6.3 , coagulation of the soy beverage occurred. It was found that qPCR could ascertain the total dead and viable population of L. reuteri in both food matrices. At day 1, the PMA-qPCR data in fruit juice were approximately $0.5 \log$ cells $/ \mathrm{mL}$ lower than in soy, which points to an effect of matrix itself on the qPCR analysis; the methodology was nevertheless successful in following the changes in L. reuteri viability during storage. Microencapsulation did not enhance the stability of the cultures.
\end{abstract}

Keywords: Lactobacillus reuteri, microencapsulation, food matrix, storage temperature PMA-qPCR

\section{INTRODUCTION}

Viability is still considered a critical component of the functionality of probiotic bacteria when they are consumed. Enumeration in plate counts (CFU) is the traditional method of evaluating viability (Champagne et al., 2011), but newer methodologies are being developed. As a function of the nature of fluorochromes that enter (or not) into viable cells, flow cytometry can be used to rapidly assess bacterial viability (Bunthof and Abee, 2002; Doherty et al., 2010). More recently, the propidium monoazide (PMA) reagent used in flow cytometry was applied to quantitative polymerase chain reaction (qPCR) to enumerate viable cells of probiotic bacteria in freeze-dried supplements (Kramer et al., 2009), and in cheddar cheese (Desfossés-Foucault et al., 2012). One of the goals of this study was to ascertain if the PMA-qPCR technique could be used in soy or fruitbased matrices as well.

Foods carrying probiotics are ideally marketed at $4^{\circ} \mathrm{C}$, and it has been shown that incubation at room temperature will reduce stability during storage (Klu $\boldsymbol{e t} \boldsymbol{a l}$., 2012; Rozada et al., 2009). However, few teams have examined the effects of storage at 8 to $10^{\circ} \mathrm{C}$ which is sometimes termed "temperature abuse". Indeed, maintaining the cold chain between 2 and $4{ }^{\circ} \mathrm{C}$ is not always respected in commercial environments, and increases may occur during shipping, display at the grocery store or in consumers' refrigerators. A few studies have shown that increasing the temperature just a few degrees into the 8 to $10^{\circ} \mathrm{C}$ range can significantly affect stability of probiotic bacteria during storage (Mortazavian $e t$ al., 2007; Rodgers and Odongo, 2002). There is interest in further documenting the evolution of viability of probiotics in the "temperature abuse" range.

In the past, the development of functional foods with probiotics was mostly based on the selection of strains which could remain viable during the processing steps as well as during storage. In the future, however, in order to obtain health claims on the labels, strain selection will primarily be made on the basis of cultures which have demonstrated health benefits supported by clinical trials. As a result, companies will need to adapt processes, or food matrix characteristics, in order to enable sufficient viability of the selected strain. There are few reports, however, on strategies that can be used to select appropriate beverages for probiotics. Lactobacillus reuteri NCIMB 30242, a strain having demonstrated clinical benefits towards serum cholesterol levels and cardiovascular risk profile (Jones et al., 2012a and 2012b), vitamin $D$ status (Jones et al., 2013a) and gastrointestinal health (Jones et al., 2013b), is currently marketed as a supplement (LRCTM, UAS Labs). This study was undertaken to ascertain if soyor fruit-based matrices can be used for this purpose. Soymilk or soy beverages have often been suggested as vehicles for the delivery of probiotic bacteria to consumers. However, in most studies with soy-based matrices, the product is fermented. There are no data on the stability of $L$. reuteri in non-fermented soy beverages.

The aims of this study were therefore to select proper fruit and soy-based beverages to carry Lactobacillus reuteri NCIMB 30242, to examine the effect of storing at 4 and $8^{\circ} \mathrm{C}$ on viability of L. reuteri in the two food matrices and to compare traditional and qPCR technologies to follow its viability during storage at 4 or $8^{\circ} \mathrm{C}$.

\section{MATERIAL AND METHODS}

\section{Preparation of Free and Microencapsulated Lactobacilli}

Lactobacillus reuteri NCIMB 30242 (LRCTM, available at UAS Labs,Madison, WI, USA) was selected for this study because of its documented effects on serum cholesterol (Jones et al., 2012a and 2012b) as well as its safety (Branton $\boldsymbol{e t}$ al., 2010; Jones et al., 2012c; Jones et al. 2012d); these parameters are required to obtain a health claim status (Health Canada, 2009). L. reuteri NCIMB 30242, proprietary to Micropharma, was propagated in modified MRS broth in anaerobic conditions (95\% nitrogen, $5 \%$ carbon dioxide) for 16 hours at $37^{\circ} \mathrm{C}$. The cultures were then centrifuged at $3,300 \mathrm{~g}$ for 20 minutes at $4^{\circ} \mathrm{C}$ and the cell pellet was isolated by gently decanting the supernatant. Free L. reuteri NCIMB 30242 was prepared by re-suspending the cell pellet in a maltodextrin and cysteine solution under proprietary conditions (Micropharma Inc., Montreal, QC, Canada) and adding the suspension dropwise to liquid nitrogen for flash freezing. Microencapsulation was carried out as described in various patents (Prakash and Jones 2010; Martoni et al. (2011). Briefly, a L. reuteri NCIMB 30242 cell pellet was blended with a low-viscosity sodium alginate solution (Sigma, Alginic acid sodium salt from brown algae; Product Number A1112; viscosity: $4-12 \mathrm{cP}, 1 \%$ in $\mathrm{H}_{2} \mathrm{O}$ at $25^{\circ} \mathrm{C}$ ) and encapsulation was performed using an Inotech Encapsulator IE50 in a sterile environment. Microbeads were allowed to solidify in a $0.1 \mathrm{M}$ calcium chloride solution followed by coating in sequential solutions of $\varepsilon$-poly-L- 
lysine and sodium alginate with intermediate wash steps. The alginate- $\varepsilon$-poly-Llysine-alginate (APA) microcapsules containing L. reuteri NCIMB 30242 were re-suspended in a solution of maltodextrin and cysteine and added dropwise to liquid nitrogen for flash freezing. The resulting frozen droplets of free and microencapsulated $L$. reuteri NCIMB 30242 were stored at $-80^{\circ} \mathrm{C}$ until used. Commercial Fruit Juices and Soy Beverages

The "Maxi mango" fruit blend was from Naked Juice (Glendora, Inc., Azusa, CA USA). The label stated that it was composed of mango, apple, orange, banana and lemon juices. The soy beverage was from Silk Original Vanilla fortified (WhiteWave Foods Company, Broomfield CO, USA). Three different production lots of each product were purchased.

\section{Chemical Analyses of Juices and Soy Beverages}

The $\mathrm{pH}$ of the products was assessed using an Accumet XL15 pH meter (Fisher Scientific, Montreal, QC, Canada). Redox level was evaluated using a portable pH meter (Oakton, Vernon Hills, IL, USA) equipped with a Combined PT-ring electrode (Metrohm, Herisau, Switzerland).

\section{Inoculation of Beverages and Bacterial Enumeration by Plate Counts}

When ready for use, a required amount of frozen culture was placed into a sterile test tube and incubated in a $37^{\circ} \mathrm{C}$ water bath for rapid thawing. This approach was used since rapid thawing is considered preferable to extended slow thawing at $4^{\circ} \mathrm{C}$ (Champagne et al., 2011). The thawed cultures were then immediately used. In some instances where the frozen cultures had high bacterial densities, they were diluted in sterile commercial freezing medium (supplied by Microparma) prior to inoculation.

The thawed cell suspension $(64 \mathrm{~mL})$ of either free or microencapsulated (ME) bacteria was added to $1.6 \mathrm{~L}$ of product, in order to achieve $1 \times 10^{8} \mathrm{CFU} / \mathrm{mL}$. For each culture, the products were fractioned into $16 \times 100 \mathrm{~mL}$ portions and placed in $120 \mathrm{~mL}$ polyethylene bottles (Salbro bottle Inc., Woodbridge, ON, Canada) The headspace was flushed with $\mathrm{N}_{2}$ and capped. Half of the bottles were placed at $4{ }^{\circ} \mathrm{C}$ while the remainder were placed at $8^{\circ} \mathrm{C}$. Bottles were always kept capped and were only opened at the sampling time. Only one bottle served for microbial and $\mathrm{pH}$ analyses. The inoculation was repeated with three different lots.

The CFU analysis of ME cultures requires special procedures (Champagne $\boldsymbol{e t}$ al., 2011). In order to have a constant sample preparation method for free or ME cultures, a procedure designed to release cells from ME culture was used on both series of samples. These samples were collected at day 1 as well as at weeks 2, 4 and 8 . They were analyzed for $\mathrm{pH}$ and viable cell counts using standard plate count assay and qPCR analyses. For CFU and qPCR, $10 \mathrm{~mL}$ of liquid containing free or ME L. reuteri NCIMB 30242 was added to $90 \mathrm{~mL}$ of citrate-peptone buffer $(25.8 \mathrm{~g} / \mathrm{L}$ trisodium citrate with $1 \mathrm{~g} / \mathrm{L}$ peptone at $\mathrm{pH} 6.8)$ in a sterile stomacher bag and homogenized with the Stomacher ${ }^{\circledR} 400$ Circulator (Seward, Worthing, West Sussex, UK) for 1 minute at $230 \mathrm{rpm}$ and another minute at low speed $(200 \mathrm{rpm})$. To allow dissolution of APA capsules, a hold period of ten minutes at room temperature was performed before proceeding to the second blending at low speed.

For CFU analyses, $1 \mathrm{~mL}$ of homogenized suspension was serially diluted in $9 \mathrm{~mL}$ of sterile buffer $(8.5 \mathrm{~g} / \mathrm{L} \mathrm{NaCl}$ with $1 \mathrm{~g} / \mathrm{L}$ peptone). Plate counts, as $\mathrm{CFU}$, were performed in duplicates by pour plating the appropriate dilutions into MRS agar which was prepared by adding $15 \mathrm{~g} / \mathrm{L}$ agar (BD-Difco) to MRS broth (Fluka; Sigma-Aldrich, St Louis, MO, USA), sterilizing at $121^{\circ} \mathrm{C}$ for $15 \mathrm{~min}$, cooling to room temperature and adding $1 \%(\mathrm{v} / \mathrm{v})$ of a filter-sterilized solution of $5 \mathrm{~g} / \mathrm{L} \mathrm{L}$-cysteine HCL. The plates were incubated for $48 \mathrm{~h}$ at $37^{\circ} \mathrm{C}$ and under anaerobic conditions.

During bacterial enumerations based on $\mathrm{qPCR}$, after the second blending, samples of $1 \mathrm{~mL}$ were taken in the stomacher bag for the propidium monoazide (PMA) treatment and DNA extraction and another sample for the comparison without PMA. The methodology follows below.

\section{Optimization of PMA Quantitative PCR}

\section{Propidium Monoazide Treatment and DNA Extraction}

The PMA treatment was carried out following the protocol of DesfossésFoucault et al. (2012). In the qPCR analysis, the treated and non-treated samples were processed with the same protocol except for the addition of PMA for the treated samples. Briefly, for the DNA extraction, cell pellets were suspended in $400 \mu \mathrm{L}$ of buffer for enzymatic lysis $(20 \mathrm{mM}$ Tris $\mathrm{HCl}$ at $\mathrm{pH} 8,2 \mathrm{mM}$ EDTA, 12 $\mathrm{g} / \mathrm{L}$ Triton X-100, $20 \mathrm{~g} / \mathrm{L}$ lysozyme) and incubated at $37^{\circ} \mathrm{C}$ for $1 \mathrm{~h}$. Then the QiaAmp DNA Stool Mini Kit (Qiagen, Mississauga, ON, Canada) was used with preliminary bead-beating step as proposed by Desfossés-Foucault et al. (2012) To ensure the quality of DNA extraction, we performed two independent extractions for each sample. With DNeasy Blood and Tissue kit, we observed PCR inhibitors in soy beverage (results not showed). In using the QIAamp DNA Stool Mini Kit, containing an InhibitEX ${ }^{\mathrm{TM}}$ tablet that removes PCR inhibitors, as well as incorporating the kit recommendation to add bovine serum albumin (BSA) to the PCR mixture, we eliminated the problem of PCR inhibitors.

\section{Primer Design and Verification of Primer Specificity}

Proprietary strain specific primers targeting L. reuteri NCIMB 30242 were designed by Micropharma Limited and confirmed for specificity against 55 strains of Lactobacillus (L. reuteri, L. fermentum, L. casei, L. acidophilus, $L$. delbrueckii and L. buchneri) as well as strains of the genus Bifidobacterium, Clostridium and Enterrococcus. The primers were further tested against animal fecal samples demonstrating their specificity for L. reuteri NCIMB 30242. qPCR was performed in triplicate using an ABI PRISM 7500 Fast real-time PCR system with software version 2.0.5 (Appl. Biosystems, Foster City, CA, USA). Amplification and detection were carried out in 96-well plates with SYBR-Green PCR 2 X Master Mix (Appl. Biosystems). Two qPCR and PMA-qPCR series of analyses were carried out because two independent DNA extractions were performed for each sampling time. Each reaction was run in a final volume of 10 $\mu \mathrm{L}$ with $0.5 \mu \mathrm{M}$ final concentration of each primer, $0.2 \mu \mathrm{g} / \mu \mathrm{L}$ of BSA and $2 \mu \mathrm{L}$ of DNA sample. The amplification program consisted of 1 cycle of $95^{\circ} \mathrm{C}$ for $20 \mathrm{~s}$ followed by 40 cycles of $95^{\circ} \mathrm{C}$ for $3 \mathrm{~s}, 55^{\circ} \mathrm{C}$ for $30 \mathrm{~s}$, followed by melting curve. Negative and positive controls were included in each run.

Determination of PMA Treatment Efficiency, Detection Limit and Standard Curves

The efficiency of PMA treatment was verified by comparing qPCR results of different ratios of live and heat-killed cells added to the beverages, as proposed by Taskin $\boldsymbol{e t ~ a l}$. (2011) (Figure 1). For this analysis, $1000 \mu \mathrm{L}$ of diluted sterilized beverages (1:10 in citrate/peptone buffer; $20 \mathrm{~min}$ in autoclave) were added to $1000 \mu \mathrm{L}$ of mixture before treating with or without PMA. DNA extraction and qPCR amplifications were performed in following the same protocol as the other samples, and the cycle threshold of each sample was then compared to a standard curve made with PMA-treated live cells $\left(10^{9}\right.$ to $\left.10^{3} \mathrm{CFU} / \mathrm{mL}\right)$. The detection limits were determined using the standard curve and treatment efficiency results.
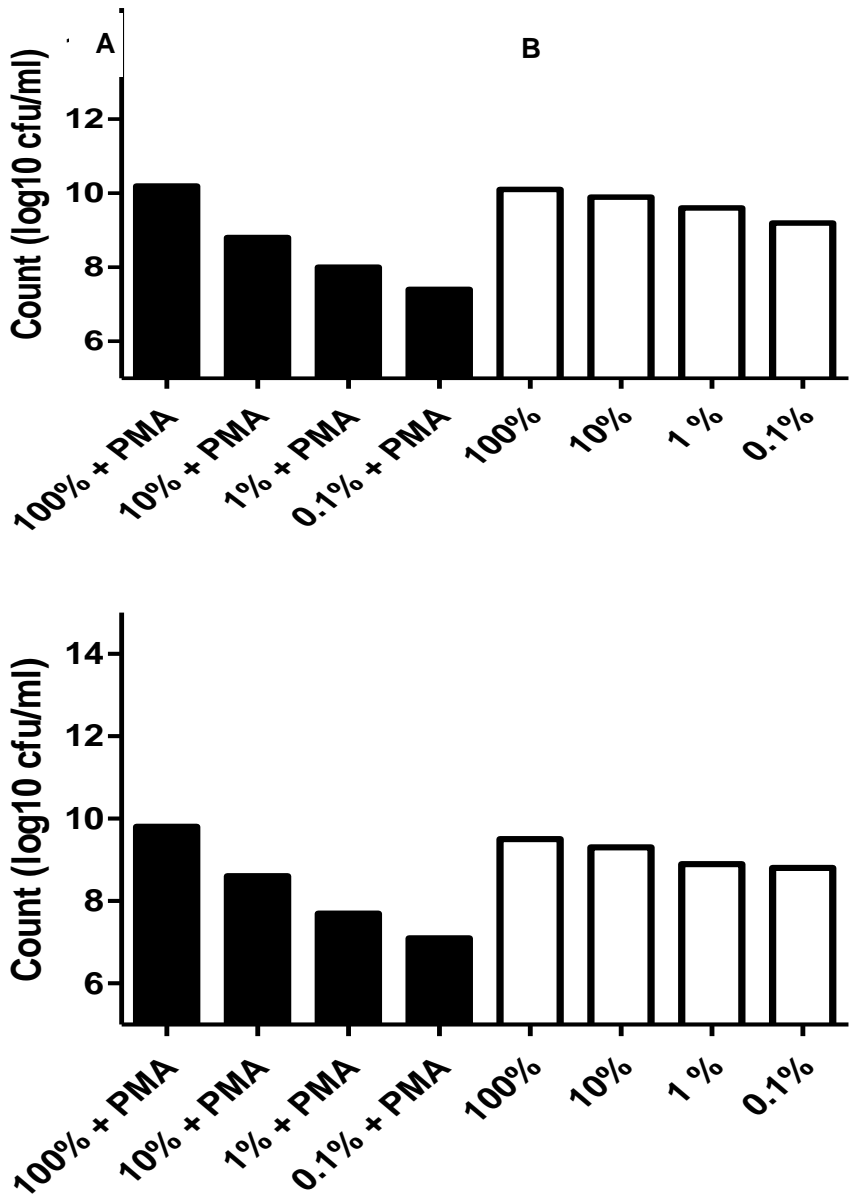

Figure 1 Effect of PMA treatment on PCR quantification of defined ratios of viable and heat-killed cells A) soy beverage and B) fruit juice.

\section{Statistical Analyses}

The inoculation of $100 \mathrm{~mL}$ beverages was made in three independent experiments, with three separate product lots. Statistical analyses on bacterial 
counts during storage were performed with the JMP 7.0 software (SAS institute) using the "Proc Mixed" procedure. First, we carried out a full factorial test and then we removed the interactions where $\mathrm{P}$ was superior to 0.40 . This approach allows reducing the model and thereby increasing the power of the test. A matched paired student test was also performed to verify the correlation between PMA-qPCR and viable count results. Correlations between different sets of data on the composition of the juice blends and their effect on bacterial growth, as well as between CFU and PMA-qPCR data, were carried out using the Spearman test from SigmaPlot version 12.5 software (Systat Software, Inc., San Jose, CA, USA).

\section{RESULTS}

Characteristics of the Food Matrices

The fruit juice blend had the following characteristics: $\mathrm{pH} 3.9$, redox level of $+123 \mathrm{mV}$. The soy beverage had a $\mathrm{pH}$ of 8.4 and a redox level of $+109 \mathrm{mV}$. Therefore, for these two parameters, the main difference between the two products was $\mathrm{pH}$.

\section{Effect of Inoculation and 1 Day of Storage on CFU Counts}

The viable counts one day after inoculation were on average $0.14 \log (38 \%)$ $\mathrm{CFU} / \mathrm{mL}$ higher in the soy beverage than in the fruit juices. This small difference was found to be statistically significant $(P=0.008)$, which is rather unusual with viable counts (Table 1). Evidently, the inoculation method, which consisted of direct inoculation with a frozen concentrate, enabled a good standardization of the experimental procedures. The higher CFU in the soy beverage was linked to a slight viability loss in the fruit juice.

\section{Evolution of pH During Storage}

The $\mathrm{pH}$ values of the soy beverage went down during storage in every condition (Figure 2). Statistical analyses showed significant effects of encapsulation (treatment), storage temperature and time (Table 1). The effect of time is quite logical, and it was to be expected that acidification would occur gradually.

At what is considered an abuse storage temperature, there was a significantly higher drop in $\mathrm{pH}$ during storage at $8^{\circ} \mathrm{C}$. As a result of all these interactions, the $\mathrm{pH}$ of $\mathrm{ME} 8^{\circ} \mathrm{C}$ in the soy beverage decreased rapidly to reach a value around $\mathrm{pH}$ 6. The decrease profile of $\mathrm{ME} 4^{\circ} \mathrm{C}$ and free $8^{\circ} \mathrm{C}$ is quite similar (not statistically different)

A very different picture emerged in the case of the fruit juice. For this matrix, the $\mathrm{pH}$ remained almost the same over 2 months storage time (Figure 3). Overall, the $\mathrm{pH}$ was not significantly affected by storage temperature or microencapsulation (Table 1)

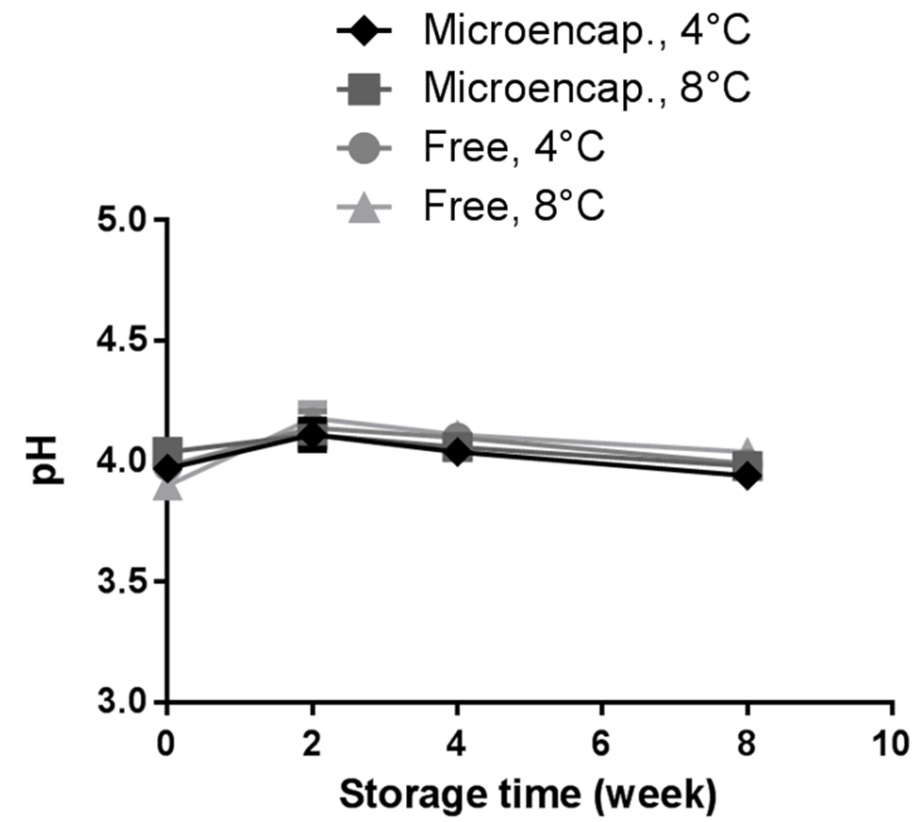

Figure 2 Evolution of $\mathrm{pH}$ in soy beverage containing Lactobacillus reuteri NCIMB 30242 during storage.

\section{Effect of Storage for Eight Weeks on Plate Counts (CFU)}

In soy beverage, the loss in viability over 8 weeks was limited to $0.2 \log$ CFU.mL ${ }^{-1}$ with free cells (Figure 4A). Although small in size, this drop in CFUs during storage became statistically significant after 4 weeks of storage. No major effect of incubating at $8^{\circ} \mathrm{C}$ on $\mathrm{CFU}$ counts was noticed. However the viability loss of the ME culture was about twice the level observed for free cells.

The CFU loss during storage in the fruit juice beverage was similarly acceptable (Figure 5A), since they were not greater than $1 \log \mathrm{CFU}$ per $\mathrm{mL}$. There were nevertheless statistically significant effects of time, incubation temperature and culture format on CFU readings. Incubation at the "abuse" temperature of $8^{\circ} \mathrm{C}$ increased the rate of viability losses, but this was limited to about 0.1 log $\mathrm{CFU} / \mathrm{mL}$. The effect of the state of the culture was of greater significance. Viability losses of free cells over the 8 week storage period were limited to about $0.3 \mathrm{Log} \mathrm{CFU} / \mathrm{mL}$ while the ME culture showed a viability drop of up to $1 \mathrm{log}$ $\mathrm{CFU} / \mathrm{mL}$ (Figure 5A).

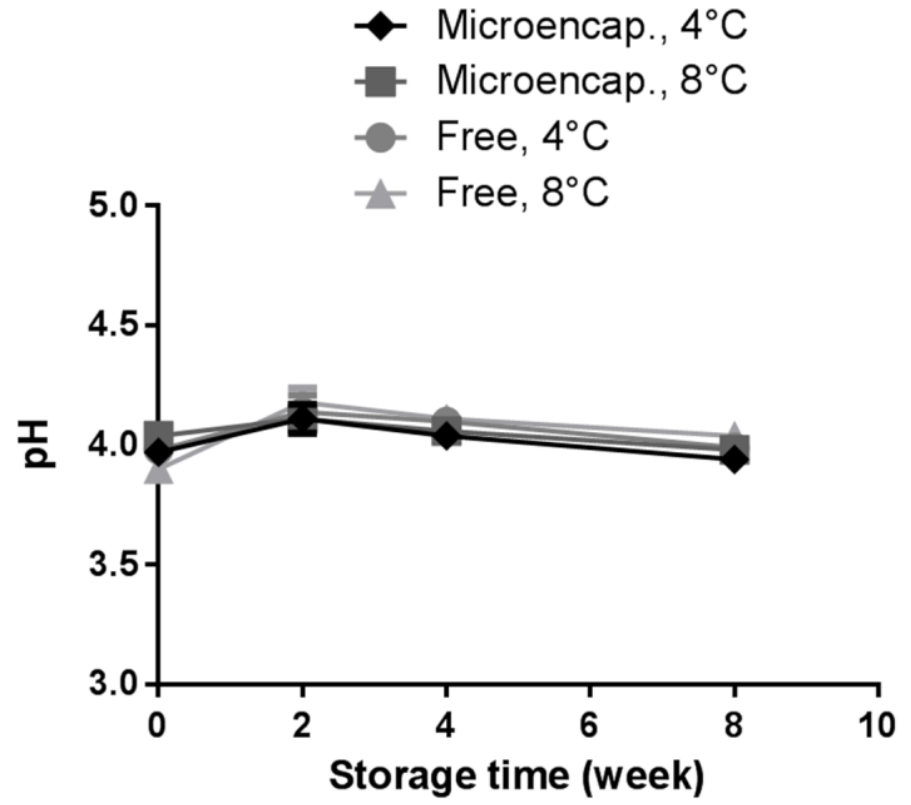

Figure 3 Evolution of $\mathrm{pH}$ in fruit juice containing Lactobacillus reuteri NCIMB 30242 during storage.

Effect of Storage on Viable + Not Cultivable Counts (PMA-qPCR)

In soy beverage, there was a significant effect $(P=0.005)$ of the cell state on PMA-qPCR viability, while the effect of storage time showed only a tendency to statistical significance $(\mathrm{P}=0.08)$ and the overall effect of storage temperature was negligible $(\mathrm{P}=0.61)$. In this series of assays in the soy beverage, the ME culture stored at $8^{\circ} \mathrm{C}$ proved to be the least stable (Figure 4B).

A different situation was noted with the fruit juice blend. There were no effects of cell state $(\mathrm{P}=0.83)$ or storage time $(\mathrm{P}=0.09)$, but incubation temperature affected PMA-qPCR viability levels $(\mathrm{P}=0.03)$. As was observed in plate counts (CFUs), a slight reduction in PMA-qPCR viability levels occurred with ME culture in fruit juice stored at $8^{\circ} \mathrm{C}$ (Figures 4 and 5). 

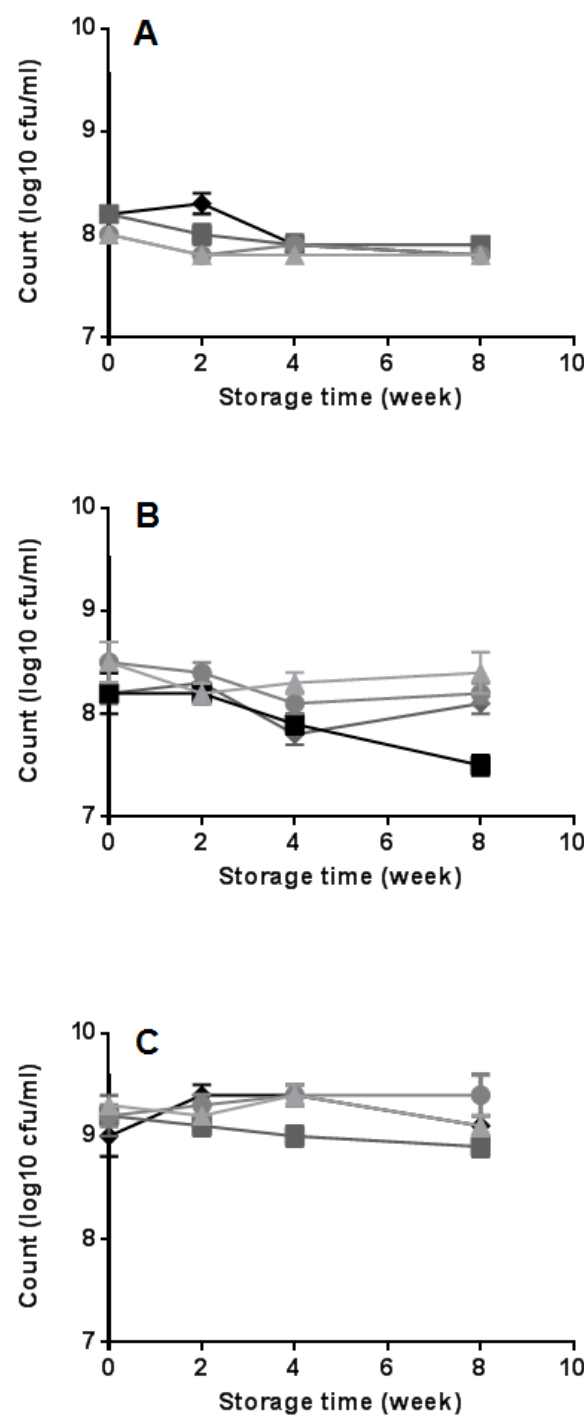

Figure 4 Number of Lactobacillus reuteri NCIMB 30242 in soy beverage during storage quantified by different methods A) plate count, B) PMA-qPCR and C) qPCR.

Overall, the CFU and PMA-qPCR data were in agreement, since the correlation coefficient $(R=+0.55)$ was statistically significant $(P=0.001)$. Therefore the PMA-qPCR could successfully be used to evaluate viability variations in the food matrices.

\section{Effect of Storage on Viable + Dead Counts (qPCR)}

With the qPCR method, without addition of PMA, we obtained, at day 1, higher values of approximately $1 \log (0.9 \log$ for soy and $1.3 \log$ for fruit) (Figures $4 \mathrm{~B}$, $4 \mathrm{C}, 5 \mathrm{~B}, 5 \mathrm{C}$ ) than for PMA-qPCR. This is explained by the fact that, without the PMA, the extracted DNA also contains that of dead cells. The aspects on viability loss resulting from inoculation in the matrix itself were discussed previously, and could account for up to $0.2 \log$ of the differences between qPCR and PMA-qPCR values, suggesting that the cell suspension used to inoculate the food matrices contained a significant proportion of non-viable cells.

When comparing ME and free-cell values at $\mathrm{T}=1$ day, data in both $\mathrm{qPCR}$ and PMA-qPCR series of data (paired $t$ test) no effect of ME $(P=0.44)$ was noted However, the food matrix had a significant effect on the qPCR data. Indeed, theoretically, qPCR values in fruit juice and soy should be identical. In practice, at $\mathrm{T}=1$ day, the data in fruit juice were approximately $0.5 \log$ cells $/ \mathrm{mL}$ lower than in soy (Figures 5B and 5C).

\section{Visual Appearance of the Soy Beverages}

While the fruit juice blend was stable in $\mathrm{pH}$ and texture over 8 weeks in all conditions, in the soy beverage there were instances where coagulation of the gel appeared. It was not established at what exact $\mathrm{pH}$ coagulation could be visually noticeable, but all soy beverage samples that had a $\mathrm{pH}$ above 7.16 were in the liquid state, while precipitation was noted in those which were at $\mathrm{pH} 6.3$ or below. For samples with free cells stored at $4^{\circ} \mathrm{C}$, a storage period of 8 weeks was possible. However, the three other treatments showed some coagulation after 4 weeks and could potentially benefit from a lower initial inoculation of $L$. reuteri.
No sensory tests on flavour were carried out, but these data on texture suggest that further tests are warranted on this important sensory aspect.
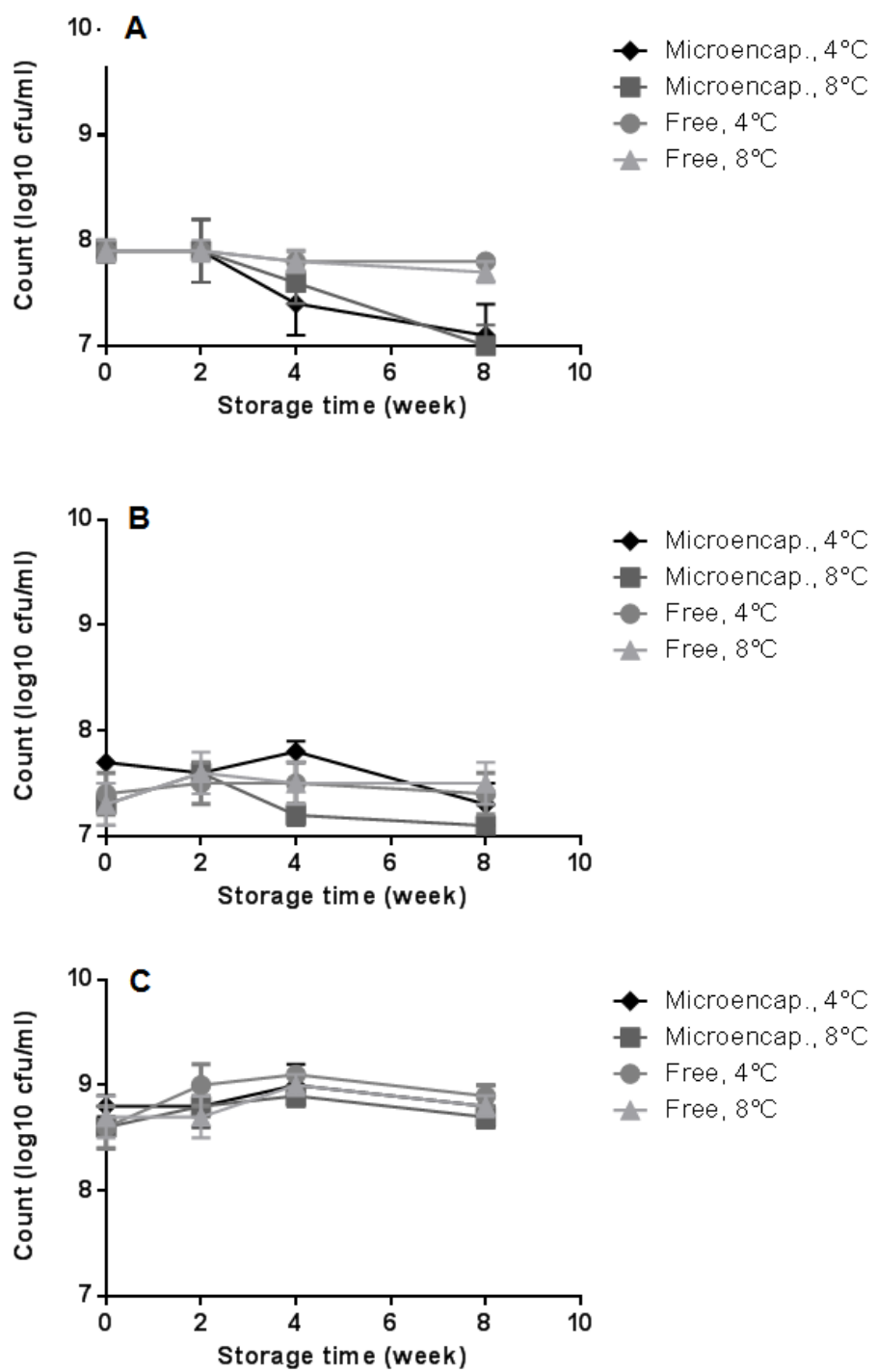

Figure 5 Number of Lactobacillus reuteri NCIMB 30242 in fruit juice during storage quantified by different methods A) plate count, B) PMA-qPCR and C) qPCR.

Table 1 Analysis of variance of the effects of experimental conditions on the evolution of $\mathrm{pH}$ in fruit juice and soy beverage. Data are the probability $(\mathrm{P})$ of an absence of effect on $\mathrm{pH}$ during storage.

\begin{tabular}{lcc}
\hline Source & Soy beverage & Fruit juice \\
\hline Microencapsulation (ME) & $<0.0001$ & 0.3375 \\
Temperature & $<0.0001$ & 0.4843 \\
Time & $<0.0001$ & 0.0005 \\
ME $*$ Temperature & 0.0002 & \\
ME $*$ Time & $<0.0001$ & \\
Temperature * Time & $<0.0001$ & \\
ME* Temperature * Time & $<0.0001$ & \\
\hline
\end{tabular}

\section{DISCUSSION}

Most scientific studies designed to evaluate the effect of changes in the composition of a food matrix on its subsequent spoilage are carried out by modifying "one parameter at a time" (such as $\mathrm{pH}$ ) or by changing "one ingredient at a time" (for example salt). Unfortunately, it becomes difficult to compare data from two very different matrices in two separate studies, because probiotic strains, experimental equipment of analytical methods differ between the two publications. This study was deliberately designed to compare two matrices having many chemical differences. Such an approach enabled the examination of a common set of experimental parameters (packaging conditions, storage temperature, analytical methods, probiotic strain, ME) on the viability of a probiotic culture as well as how it can spoil the food matrix. 


\section{Effect of pH on Viability}

On the basis of CFU values immediately following inoculation or after day 1 , data suggest that inoculation in fruit juice would need to be between 0.14 and 0.5 $\log \mathrm{CFU} / \mathrm{mL}$ higher than in the soy product to obtain similar viable counts at the end of storage. A rapid viability loss upon inoculation in juice has been reported (Reid et al., 2007), but this was not the only reason for the differences between soy and fruit juice CFU data at day 1 . Indeed, CFUs in the soy beverage after day 1 are slightly higher that would theoretically be found after inoculation. This suggests slight growth.

The stability of probiotics during storage in food matrices is strongly influenced by pH, (Kailasapathy et al., 2008; Nualkaekul and Charalampopoulos, 2011) and the redox level (Bolduc et al., 2008). Even when blends of various juices enable the product to be adjusted at $\mathrm{pH} 4.2$, viability losses of up to $5 \mathrm{log}$ $\mathrm{CFU} / \mathrm{mL}$ occur over 60 days of storage, as a function of strain and species (Saarela et al., 2006; Champagne and Gardner, 2008). In this study, L. reuter showed good stability in a juice blend during 60 days of storage, which was in line with the data on another strain of the same species (Champagne and Gardner, 2008). These results suggest that L. reuteri is a good candidate for enrichment of fruit juices.

Studies on the effect of storage $\mathrm{pH}$ on viability have examined acid environments. To our knowledge, no stability studies have been made for $L$. reuteri at alkaline $\mathrm{pH}$ levels, and the high $\mathrm{pH}$ of 8.6 of the soy beverage was a concern. The $L$. reuteri NCIMB 30242 culture was more stable in the soy beverage than the fruit juice. Evidently, a slightly alkaline environment is less detrimental that an acid one for stability of this strain during storage.

\section{Effect of Probiotics on Matrix pH}

No data exist on the effect of high inoculation levels of L. reuteri $\left(10^{8} \mathrm{CFU} / \mathrm{mL}\right)$ in unfermented soy beverages. In cow milk however, which is arguably the closest comparative food matrix, considerable variations in $\mathrm{pH}$ can occur during storage as a function of strain, inoculation level and storage temperature (Saarela et al., 2006; Bolduc et al., 2006; Sanders et al., 1996). In a study involving eigh strains of bifidobacteria inoculated at approximately $7.2 \log \mathrm{CFU} / \mathrm{mL}$, the $\mathrm{pH}$ of milk after a two week incubation at $4^{\circ} \mathrm{C}$ varied between 6.68 (e.g. no change) and 5.31 as a function of strain and redox level of milk (Bolduc et al., 2006) Sanders et al. (1996) also reported acidification to pH 5.5 over 3 weeks storage, while Saarela et al. (2006) did not find any. In light of this literature, it appears that the L. reuteri NCIMB 30242 culture used in this study is not a highlyacidifying culture under refrigeration conditions if kept at $4^{\circ} \mathrm{C}$. Since data show that there is nevertheless acidification, industry might take advantage of the opportunities allowing for adjustment in buffering capacity of the products Indeed, a soy beverage would be more sensitive to a $\mathrm{pH}$ drop than milk because its buffering capacity is lower (Zare et al., 2011).

\section{Microencapsulation}

Acidification tended to be higher with the ME culture, which is in line with the observations of Truelstrup-Hansen et al., (2002) in unfermented milk. The greater acidification of the soy beverage with the ME cultures, as compared to free cells was, nevertheless, unexpected. With the exception of dry sausage fermentation (Kearney et al., 1990), at optimum fermentation temperatures (about $37^{\circ} \mathrm{C}$ for probiotics), ME cultures in alginate gels have lower specific acidifying properties than free cells (Champagne et al., 1988). The potentia differences in physiological state between free and ME cells was examined by comparing, in paired t tests, the CFU and PMA-qPCR data of samples. There was no significant difference, which suggests that, the free and ME cells appeared similar with respect to membrane properties and culturability. Therefore, the differences between free and ME in this study should be investigated further.

Since CFUs in soy beverage were higher at day 1 than those at inoculation, it must be assumed that some growth occurred. Therefore, the higher values in CFU with free cells, in comparison to ME cultures, might partially reflect better growth of the free cells following inoculation rather than a lack of protective effect of ME.

\section{Effect of storage temperature}

Although the products should be kept between 1 and $4^{\circ} \mathrm{C}$, their temperature often rises during shipping, or during storage in retail outlet refrigerators (Juneja et al., 2006). Even between 0 and $10^{\circ} \mathrm{C}$, there can be an increase in acidification during storage (Micanel $\boldsymbol{e t}$ al., 1997) and lesser stability of probiotics (Mortazavian $\boldsymbol{e}$ al., 2007). Since $\mathrm{pH}$ affects the viability of probiotics during storage (Roy, 2005; Kailasapathy et al., 2008), as well as sensory properties, evaluation of the evolution of $\mathrm{pH}$ during this period is warranted.

In soy, storing at $8^{\circ} \mathrm{C}$ promoted acidification. In contrast, the $\mathrm{pH}$ of fruit juice inoculated with free or ME cells remained stable during storage at both temperatures. This is in agreement with data in the literature in instances where $\mathrm{pH}$ of the various juices were in the 3.7-4.1 range (Elizaquível et al., 2011; Saarela et al., 2006). Presumably, the highly sub-optimal $\mathrm{pH}$ environment strongly reduced metabolic activities and prevented an abuse storage temperature to become a problem. This study therefore shows that the nature of the food matrix influences the impact of inadequate storage temperature on the spoilage which results from the presence of probiotic cultures.

\section{PMA-qPCR for bacterial counts}

The CFU methodology is a classical technique, but it requires an extensive incubation period. New techniques which provide more rapid responses are on viable and total counts are required. This study was very appropriate to validate the recently-developed PMA-qPCR methodology. Indeed, the state of the cells could be affected by the food matrix ( $\mathrm{pH}$, fat, protein etc.) as well as by microencapsulation, ant it provided unique comparative conditions to assess the PMA-qPCR technique. This study confirmed the data of Desfossés-Foucault et al. (2012) to the effect that PMA-qPCR is a reliable methodology is assessing viable counts in a food matrix. It is the first study, however, to examine the effect of very different food matrices on its results. In food microbiology, it is well known that the nature of the food matrix will influence the results of microbial analyses. For example, the CFU analytical procedure carried out on yogurt would not be appropriate with cheese. In yogurt, sample homogenization can be carried out at room temperature with a peptone buffer as diluent. Such an approach would result in an underestimation of CFUs from a cheese sample, since homogenization at $40^{\circ} \mathrm{C}$ in a citrate buffer is best with cheese (Duncan et al., 2004) because it enables a more extensive release of cells from curds.

The good correlation between CFU values and PMA-qPCR in both matrices, means that PMA-qPCR can follow the viability of L. reuteri NCIMB 30242 in fruit juice and a soy beverage. However, for identical inoculation levels, qPCR data in soy were slightly higher than those in fruit juice. This could be due to an effect of the matrix itself on the qPCR analysis, or greater autolysis of cells in the fruit juice. It could also be hypothesized that some growth occurred in the soy beverage during day 1 . Further studies on the nature of the effect of the food matrix on qPCR data are therefore warranted.

\section{Lactobacillus reureti NCIMB 30242 for Foods}

Data from this study were compared with those in the literature in order to ascertain the position of $L$. reuteri NCIMB 30242 as a strain of commercial interest. Again, since there are no data in non-fermented soy beverages with $L$. reuteri, our comparative examination was carried out on data from unfermented milk. In such products, loss of viability of other probiotics is typically less than 1 $\log$ CFU/mL (Sanders et al., 1996; Saarela et al., 2006; Truelstrup-Hansen et al., 2002). However, as a function of strains and how they are prepared, viability losses varying from none (Saarela et al., 2006; Truelstrup-Hansen et al., 2002) to $5 \log$ CFU/mL (Bolduc et al., 2006; Truelstrup-Hansen et al., 2002) of bifidobacteria have been reported. In light of these literature data, L. reuteri NCIMB 30242 can be considered as a stable culture in a soy beverage and compares favourably to those observed in the literature under similar conditions.

\section{CONCLUSION}

Soy beverages and fruit juices can successfully be used to deliver viable $L$. reuteri probiotics since losses were lower than $1 \log$ CFU per $\mathrm{mL}$. In addition, if stored in appropriate refrigerated conditions with an appropriate culture format, L. reuteri NCIMB 30242 can be delivered at a more than 10 billion cells per 250 $\mathrm{mL}$ portion without negatively impacting the texture of foods. This is 10 times more than most food products on the market, which currently deliver 1 billion cells per portion. Most studies on the stability of probiotics during storage in foods examine the effect of strain or ingredients in a single matrix. This study showed that developing a new food product with a given strain holds many challenges.

This study also contributes novel observations for the sector: 1) qPCR and PMAqPCR can be used to ascertain the total dead and viable population of $L$. reuteri NCIMB 30242 in fruit juices and soy beverages, and data of the latter are in agreement with $\mathrm{CFU}, 2$ ) the food matrix affects viability readings of $L$. reuter NCIMB 30242, as verified by PMA-qPCR, 3) microencapsulation was not effective in enhancing viability during storage in the fruit juice $(P=0.3375), 4)$ increasing the temperature from $4^{\circ} \mathrm{C}$ to $8^{\circ} \mathrm{C}$ only has minor effects on growth or viability losses over 8 weeks of storage but 5) when the soy beverages are inoculated at $10^{8} \mathrm{CFU} / \mathrm{mL}$, significant drops in $\mathrm{pH}$ occur during storage and particularly at $8^{\circ} \mathrm{C}(\mathrm{P}<0.0001)$.

Acknowledgments: This work was partially supported by a grant from the Engage program of the Natural Sciences and Engineering Research Council of Canada. Gratitude is expressed towards Yves Raymond for technical assistance.

\section{REFERENCES}

BOLDUC, M.-P., RAYMOND, Y., FUSTIER, P., CHAMPAGNE, C.P., VUILLEMARD, J.-C., 2006. Sensitivity of bifidobacteria to oxygen and redox 
potential in non-fermented pasteurized milk. Int. Dairy J. 16,1038-1048 http://dx.doi.org/10.1016/j.idairyj.2005.10.030

BRANTON, W.B., JONES, M.L., TOMARO-DUCHESNEAU, C., MARTONI, C.J., PRAKASH, S., 2010. In vitro characterization and safety of the probiotic strain Lactobacillus reuteri Cardioviva NCIMB 30242. Int. J. Probiotics Prebiotics, 6, 1-12.

BUNTHOF, C.J. AND ABEE, T., 2002. Development of a flow cytometric method to analyze subpopulations of bacteria in probiotic products and dairy starters. Appl. Environ. Microbiol. 68, 2934-2942. http://dx.doi.org/10.1128/AEM.68.6. 2934-2942.2002

CHAMPAGNE C.P., GARDNER N.J. 2008. Effect of storage in a fruit drink on subsequent survival of probiotic lactobacilli to gastro intestinal stresses. Food Res. Int. 41, 539-543. http://dx.doi.org/10.1016/j.foodres.2008.03.003

CHAMPAGNE, C. P., BAILlARGEON-COTE, C., GOULET, J., 1988 Fermentation of whey by immobilized Lactobacillus helveticus cells. Can. Inst Food Sci. Technol. J. 21, 403-407.

CHAMPAGNE, C.P., ROSS, R.P., SAARELA, M., HANSEN, K.F., CHARALAMPOPOULOS, D., 2011. Recommendations for the viability assessment of probiotics as concentrated cultures and in food matrices. Int. $J$.

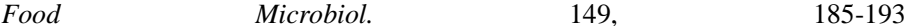
http://dx.doi.org/10.1016/j.ijfoodmicro.2011.07.005

DESFOSSÉS-FOUCAULT, E., DUSSAULT-LEPAGE, V., LE BOUCHER, C. SAVARD, P., LAPOINTE, G., ROY, D., 2012. Assessment of probiotic viability during Cheddar cheese manufacture and ripening using propidium monoazidePCR quantification. Front Microbiol. 3 (Article 350) 1-11. http://dx.doi.org/10.3389/fmicb.2012.00350

DOHERTY, S.B., WANG, L., ROSS, R.P., STANTON, C., FITZGERALD, G.F., BRODKORB, A., 2010. Use of viability staining in combination with flow cytometry for rapid viability assessment of Lactobacillus rhamnosus GG in complex protein matrices. J. Microbiol. Meth. 82, 301-310. http://dx.doi.org/10.1016/j.mimet.2010.07.003

DUNCAN, S.E., YAUN, B.R. AND SUMMER, S.S. (2004) Microbiologica methods for dairy products. Chapter 9 in, Standard methods for the examination of dairy products, $17^{\text {th }}$ edition. American Public Health Association, Washington DC, USA, p 259.

ELIZAQUÍVEL, P., SÁNCHEZ, G., SALVADOR, A., FISZMAN, S., DUEÑAS, M.T., LÓPEZ, P., FERNÁNDEZ DE PALENCIA, P., AND AZNAR, R., 2011. Evaluation of yogurt and various beverages as carriers of lactic acid bacteria producing 2-branched (1-3)-B-D-glucan. J. Dairy Sci. 94, 3271-3278 http://dx.doi.org/10.3168/jds.2010-4026

HEALTH CANADA, 2009. Guidance document for preparing a submission for food health claims. Bureau of Nutritional Sciences, Food Directorate, Health Products and Food Branch. http://www.hc-sc.gc.ca/fn-an/legislation/guideld/health-claims_guidance-orientation_allegations-sante-eng.php

JONES, M.L., MARTONI, C.J., PARENT, M., PRAKASH, S., 2012a Cholesterol-lowering efficacy of a microencapsulated bile salt hydrolase-active Lactobacillus reuteri NCIMB 30242 yoghurt formulation in hypercholesterolaemic adults. British J. Nutr. 107, 1505-1513. http://dx.doi.org/10.1017/S0007114511004703

JONES, M.L., MARTONI, C.J., PRAKASH S., 2012b. Cholesterol lowering and inhibition of sterol absorption by Lactobacillus reuteri NCIMB 30242: a randomized controlled trial. Euro J. Clin. Nutr. 66, 1234-1241. http://dx.doi.org/10.1038/ejen.2012.126

JONES M.L., MARTONI C.J., PRAKASH S., 2013a. Oral supplementation with probiotic $L$. reuteri NCIMB 30242 increases mean circulating 25-hydroxyvitamin D: a post hoc analysis of a randomized controlled trial. J. Clin. Endocrinol. Metab. 98, 2944-2951. http://dx.doi.org/10.1210/jc.2012-4262

JONES M.L., MARTONI C.J., GANOPOLSKY J.G., SULEMANKHIL I, GHALI P, PRAKASH S., 2013b. Improvement of gastrointestinal health status in subjects consuming Lactobacillus reuteri NCIMB 30242: a post-hoc analysis of a randomized controlled trial. Expert Opin. Biol. Ther. 13: 1643-1651. http://dx.doi.org/10.1517/14712598.2013.833601

JONES M.L., MARTONI C.J., TAMBER, S, PARENT, M., PRAKASH, S 2012c. Evaluation of safety and tolerance of microencapsulated Lactobacillus reuteri NCIMB 30242 in a yogurt formulation: A randomized, placebocontrolled, double-blind study. Food Chem. Toxicol. 50, 2216-2223. http://dx.doi.org/10.1016/j.fct.2012.03.010

JONES, M.L., MARTONI, C.J., DI PIETRO, E., SIMON, R.R., PRAKASH, S 2012d. Evaluation of clinical safety and tolerance of a Lactobacillus reuter NCIMB 30242 supplement capsule: A randomized control trial. Regulat. Toxicol. Pharmacol. 63, 313-320. http://dx.doi.org/10.1016/j.yrtph.2012.04.003

JUNEJA, V. K., XUETONG F., PENA-RAMOS, A., DIAZ-CINCO, M., PACHECO-AGUILAR, R., 2006. The effect of grapefruit extract and temperature abuse on growth of Clostridium perfringens from spore inocula in marinated, sous-vide chicken products. Innov. Food Sci. Emerging Technol. 7 , 100-106, http://dx.doi.org/10.1016/j.ifset.2005.09.004

KAILASAPATHY, K., HARMSTORF, I., PHILLIPS, M., 2008. Survival of Lactobacillus acidophilus and Bifidobacterium animalis ssp. lactis in stirred fruit yogurts. LWT- Food Sci. Technol. 41, 1317-1322. http://dx.doi.org/10.1016/j.1wt. 2007.08.009
KEARNEY, L., UPTON, M., MCLOUGHLIN, A., 1990. Enhancing the viability of Lactobacillus plantarum inoculum by immobilizing the cells in calciumalginate beads incorporating cryoprotectants. Appl. Environ. Microbiol. 56, 3112 3116

KLU, Y.A.K., WILLIAMS, J.H., PHILLIPS, R.D., CHEN, J., 2012. Survival of Lactobacillus rhamnosus GG as influenced by storage conditions and product matrixes. J. Food Sci. 77, M659-M663. http://dx.doi.org/10.1111/j.1750 3841.2012.02969.x

KRAMER, N., OBERMAJER, N., MATIJAŠIĆ, B.B., ROGELJ, I., KMETEC, V., 2009. Quantification of live and dead probiotic bacteria in lyophilised product by real-time PCR and by flow cytometry. Appl. Microbiol. Biotechnol. 84, 1137 1147. http://dx.doi.org/10.1007/s00253-009-2068-7

MARTONI, C.J., JONES, M.L., PRAKASH, S., 2011. Epsilon Poly-L-Lysine capsules. Patent WO/2011/ 075848 (PCT/CA2010/002057)

MICANEL, N., HAYNES, I.N., PLAYNE, M.J., 1997. Viability of probiotic cultures in commercial Australian yogurts. Austral. J. Dairy Technol. 52, 24-27.

MORTAZAVIAN, A.M., EHSANI, M.R., MOUSAVI, S.M., REZAEI, K., SOHRABVANDI, S., REINHEIMER, J.A., 2007. Effect of refrigerated storage temperature on the viability of probiotic micro-organisms in yogurt. Int. J. Dairy Technol. 60,123-127. http://dx.doi.org/10.1111/j.1471-0307.2007.00306.x NUALKAEKUL, S., CHARALAMPOPOULOS, D., 2011. Survival of Lactobacillus plantarum in model solutions and fruit juices. Int. J. Food Microbiol. 146, 111-117. http://dx.doi.org/10.1016/j.ijfoodmicro.2011.01.040 PRAKASH, S., JONES, M.L., 2010. Cell and enzyme composition for modulating bile acids, cholesterol and triglycerides US Patent 2010/0074933 A1. REID A.A., CHAMPAGNE C.P., GARDNER N., FUSTIER P., VUILLEMARD J.C. 2007. Survival in food systems of Lactobacillus rhamnosus R0011 microentrapped in whey protein gel particles. J. Food Sci. 72(1), M31-M37. http://dx.doi.org/10.1111/j.1750-3841.2006.00222.x

RODGERS, S. ODONGO, S., 2002. Survival of Lactobacilus acidophilus, L. casei and Bifidobacterium lactis in coleslaw during refrigerated storage. Food Austral., 54, 185-188.

ROY, D., 2005. Technological aspects related to the use of bifidobacteria in dairy products. Lait, 85, 39-56. http://dx.doi.org/10.1051/lait:2004026

ROZADA, R., VÁZQUEZ, J.A., CHARALAMPOPOULOS, D., THOMAS, K. PANDIELLA, S.S., 2009. Effect of storage temperature and media composition on the survivability of Bifidobacterium breve NCIMB 702257 in a malt $\begin{array}{llllll}\text { hydrolisate. Int. J. Food Microbiol. } & 133, & 14-21\end{array}$ http://dx.doi.org/10.1016/i.ijfoodmicro.2009.04.003

SAARELA, M., VIRKAJARVI, I., ALAKOMI, H.L., SIGVARD-MATTILA, P., MATTO, J., 2006. Stability and functionality of freeze-dried probiotic Bifidobacterium cells during storage in juice and milk. Int. Dairy J. 16, 1477 1482. http://dx.doi.org/10.1016/j.idairyj.2005.12.007

SANDERS, M. E., WALKER, D. C., WALKER, K. M., AOYAMA, K KLAENHAMMER, T.R., 1996. Performance of commercial cultures in fluid milk applications. J. Dairy Sci. 79, 943-955.

TASKIN, B., GOZEN, A.G., DURAN, M., 2011. Selective quantification of viable Escherichia coli bacteria in biosolids by quantitative PCR with propidium monoazide modification. Appl. Environ Microbiol. 77, 4329-4335. http://dx.doi.org/10.1128/AEM.02895-10

TRUELSTRUP-HANSEN, L., ALLAN-WOJTAS, P. M., JIN, Y. L. PAULSON, A. T., 2002. Survival of Ca-alginate microencapsulated Bifidobacterium ssp. in milk and simulated gastrointestinal conditions. Food Microbiol.,19, 35-4 http://dx.doi.org/10.1006/fmic.2001.0452

ZARE, F., BOYE, J. I., ORSAT, V., CHAMPAGNE, C., SIMPSON, B. K. 2011. Microbial, physical and sensory properties of yogurt supplemented with lentil flour. Food Res. Int. 44, 2482-2488 http://dx.doi.org/10.1016/j.foodres.2011.01.002 